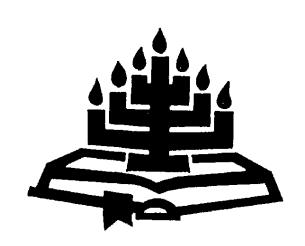

\title{
Doing trinitarian theology: primary references to God and imagination ${ }^{1}$
}

\author{
R. Venter \\ Department of Dogmatology \\ Faculty of Theology \\ University of the Free State \\ BLOEMFONTEIN \\ E-mail: rianventer@mweb.co.za
}

\begin{abstract}
Doing trinitarian theology: primary references to God and imagination
\end{abstract}

This article explores methodology in trinitarian theology and proposes one possible avenue to the question of how it should be done. The basic argument highlights the multiple functions of references to God in theological discourse. Three of these potential ways are discussed, namely God as Agent, God as Model, and God as Heuristic Principle. The various references are explained with examples taken from Scripture and contemporary trinitarian proposals. A picture emerges of sophisticated rhetorical strategies being employed by theologians. By identifying some of the functions of God-references, the article not only emphasises the imaginative and constructive nature of theological reflection, but also contributes to the question of the possibilities of trinitarian theology and its development.

\section{Opsomming}

Beoefening van triniteitsteologie: primêre verwysings na God en verbeelding

Hierdie artikel ondersoek metodologieë van die triniteitsteologie en stel een moontlike weg voor vir die beoefening daarvan. Die basiese argument beklemtoon hoe die verwysings na God verskillende funksies kan hê gedurende teologiese diskoerse.

1 Edited version of a short paper presented at the Annual Conference of the Society for the Study of Theology, Kontakt der Kontinenten, The Netherlands, 30 March-2 April 2009. 
Drie van hierdie verwysings word bespreek, naamlik God as die Handelende, God as Model, en God as Heuristiese Beginsel. Hierdie verwysings word verduidelik aan die hand van voorbeelde uit die Skrif en in kontemporêre triniteitsvoorstelle. 'n Beeld van gesofistikeerde strategieë wat deur teoloë gebruik word, kristalliseer. Deur van hierdie funksies wat na God verwys, te identifiseer, lig die artikel nie net die verbeeldingsmatige en konstruktiewe aard van teologiese refleksie uit nie, maar dra terselfdertyd ook by tot die vraag na die moontlikhede van triniteitsteologie en die ontwikkeling daarvan.

\section{Introduction}

This article explores one of the open questions in the burgeoning trinitarian discourse. It is possible to map some trends, sensibilities, advances, and the obvious differences which profile this reflection. Excellent work also provides informative overviews of the developments. ${ }^{2}$ In my opinion, a stocktaking of the present state of scholarship reveals the need to attend more explicitly to methodological questions. Once the importance of the trinitarian confession has been accepted, the inevitable challenge, namely how to "think Trinitarianly" crystallises (Gunton, 2003:7). This short article is a mere exercise in one aspect of methodology.

The basic proposal of the article suggests that various kinds of references to God are found in theological discourse and that a deliberate distinction and intentional use of these may intimate an avenue for doing creative trinitarian theology. In contemporary literature on trinitarian theology at least three different qualitative and primary "uses" of or "references" to God can be identified: God as Agent, God as Model, and God as Heuristic Principle, each of these functions in a distinct manner. In theological discourse as linguistic practice, language refers intentionally; the focus in this instance is on how God as language-construct refers and functions within a particular, theological, universe. ${ }^{3}$

An acceptance and conscious use of diverse references to God may result in a more comprehensive and consistent trinitarian theology. If the reconstruction of traditional doctrine, and ultimately the inter-

2 See e.g. Van den Brink (2003), Grenz (2004) and Kärkkäinen (2007), as well as Hunt (2005).

3 Reference has to do with linguistic denotation, and presupposes a particular universe in the discourse. Cf. Cotterell and Turner (1989:82-89). 
pretation of reality from a trinitarian perspective 4 is at stake, such a proposal may contribute to the vitality of the project. For example, if one were to develop an anthropology along trinitarian lines, or answer questions about truth, morality and beauty from a trinitarian perspective, how would one proceed? The unfathomable richness of the triune God's life should also inform the character of discourse as such.

Two qualifications may be appropriate before the proposal is discussed. This article is an initial exercise in trinitarian rhetoric, and an attempt to investigate the way theological arguments are construed. Rhetoric is about persuasion, power and effects. Different references should, however, be distinguished from performative impacts. The scope of the article can address only the first issue of references. Secondly, the proposal neither excludes the possibility of other methodological proposals for doing trinitarian theology, nor implies that additional kinds of references to God could not be identified.

\section{References to God}

The discussion of the three references to God will briefly explain each reference, offer illustrations from a major new theological text 5 and from contemporary challenges, highlight problems, and suggest ways to utilise it in a comprehensive and constructive trinitarian approach.

\subsection{Agency and Trinity}

To speak of Father, Son and Spirit acting and doing is arguably the most elementary way of referring to God. "The God who acts" has become cemented as a shorthand way of understanding God in the Old Testament (cf. Fretheim, 1997). The incarnation and life of the earthly Jesus and Pentecost convey a sense of divine action and movement. The early creeds, celebrated in baptism, were construed along the lines of a trinitarian drama. The traditional ascription of creation, salvation and consummation to the three Persons of the triune God underscores the appreciation of divine agency. The

4 Schwöbel (1995:1) correctly remarks that "Reflection on the Trinity ... has repercussions for the whole project of Christian theology, and its relation to the cultural situation of the times". 
development of the trinitarian doctrine was an attempt to interpret and make sense of divine dealing with creation and humankind. The christian character of any theology neglecting the divine agency could be questioned (cf. Schwöbel, 1987:225).

An obvious candidate, for an illustration, would be the doctrine of providence. Traditionally discussions and treatments of this doctrine have been in the suffocating grip of generic and deterministic speaking. A deliberate and conscious trinitarian reconstruction would speak in a more nuanced manner. To revise a deterministic understanding of providence Fergusson (2006:164) points to the neglect of pneumatology in traditional approaches. According the Holy Spirit a more prominent place may contribute to an understanding of creation less as an expression of a divine scheme and more as a project under construction. The world being perfected by the ongoing work of the Spirit assumes its freedom as God's covenant partner. Fergusson (2006:165) adds, and this is crucial for the present focus, that providence "... need not restrict itself to any single model of divine action". Several types of divine involvement are theologically tenable. This is what a fully trinitarian approach may entail. Unfortunately Fergusson does not explore a christological dimension. Considering the continuous work of the crucified Christ as Lord would open new avenues for understanding providence.

To this example from the Moltmann Festschrift one can add a further illustration. In an evolutionary era the question about divine agency has become a particular urgent matter to address. A consistent trinitarian approach allows the introduction of the notion of kenosis and of the cosmic Spirit which is life giving. Potentially, christological self-limitation makes room for contingency and freedom in creation, and offers a pneumatic explanation for the thrust towards greater complexity. Generic speaking about God displays an inherent theological limitation to engage evolutionary thinking apologetically. Trinitarian thinking, however, opens new possibilities for the faith-science dialogue (see e.g. Edwards, 1999).

A first impression may be that doing trinitarian theology from the perspective of differentiated divine agency is uncomplicated and requires only a holistic and inclusive take on biblical material. This would be erroneous; the intense problematic nature of this endeavour should be realised. Trinitarian agency cannot be envisioned apart from the conflicts with the faith/science debate (cf. e.g. Tracy, 2003), and intracanonical tensions. A post-Enlightenment world has little need for the explanatory power of God. The action of the triune God should be theologically navigated in the tensions present in 
Scripture of the love of God and the unmistaken "dark side" of the same God in the Old Testament, of the cross and resurrection, of creation and redemption, and the Spirit's relation with Father and Son, and its relative independence. Doing trinitarian systematic theology is never a simplistic compilation of biblical texts; it is a constructive task wrought with challenges, but also with endless possibilities. For example, these intracanonical tensions may provide a key to addressing traditional conundrums in providence, like the question of suffering.

The implication of this central christian conviction and practice for doing theology is obvious. Unfortunately, for too long, theological construction has been suffering from reductionist and generic reference to God. The kaleidoscopic testimony of Scripture to the divine action should be considered in each case. For example, christological and pneumatological perspectives must come into play and enrich and redefine the reflection. Basically doing trinitarian theology entails recognising and integrating the various voices in the Bible pertaining to the work of the Father, Son and Spirit related to the issue at hand. The plurality of traditions which Old Testament and New Testament theology identify and record should be considered. The final result would never be a simplistic compilation. The very work of the triune God is too rich and too diversified for that. In addition to the complexity of the biblical testimony, a certain symbolising of the action itself would come into play. For example, incarnation and cross carry a reservoir of meaning, a cipher filled with meaning, which should be explored. Such divine events become occasions, which allow speaking of self-emptying or absence in presence. Agency cannot be considered separate from the symbolic potential, and this opens vast possibilities for a trinitarian imagination and for employing God in other senses.

\subsection{Modelling and Trinity}

Over the past decades a second and popular way of referring to God in theological literature emphasises that God is a model, an example who should somehow inform human, ecclesial and social life. God as theological reference functions in a different way than in the previous approach. This entire constellation of approaches to trinitarian thinking is often labelled as social Trinitarianism (cf. Thompson, 1997). The differentiated divine life as communion of three Persons is highlighted with an appreciation of relationality as revealing key of the divine mystery. The quality of intradivine relationships has become a normative standard to be imitated or to be echoed 
(Gunton, 1997:78) by man, church or society. A standard vocabulary has developed which conveys the central insights, for example, the one and the many, unity in diversity, mutuality, reciprocity, generosity, and gifting.

One of the intriguing examples of the recent proposals in the English Festschrift for Moltmann could be mentioned. Meeks (2006) investigates the importance of the social trinity to revise theories and practices of property as an aspect of political economy. The doctrine of the social trinity criticises the concepts of God used to justify dehumanising approaches to property. Dominant western understandings of God conceive of God as mastery and self-possession. Correspondingly this encourages a market view of the human being, namely that I own and possess myself, human freedom becomes mastery and everything is commodified. According to Meeks (2006: 18 ), trinity implies "God's owning is not grounded in self-possession but rather in self-giving ... God 'has' God's self precisely in giving God's self". He continues (2006:20) that "everything about our lives should be a reflection of this gift". Property is understood in terms of reciprocity, redistribution and gifting. Ultimately an economy of grace replaces an economy of debt.

The position of the other, that is those who are, for example, different sexually, racially, culturally, has taken centre stage in contemporary ethical reflection. Human society struggles to come to terms with difference and otherness. Numerous forms of discrimination and even violence can be mentioned. What is the potential impact of a specific God-image? The Christian God is conspicuously otherwelcoming: the creation was an act of welcoming the other over against God-self; the incarnation was an assumption of the human nature; salvation is the acceptance of the sinner. Trinitarian theology speaks the grammar of hospitality. If this very character of God is "imitated", is followed as an example, a specific self would be construed - a self that creates space for the other. Xenophobia, racism, sexism - all could be transformed if the triune God becomes the principle for an ethos.

A social understanding and conceptualisation of God has resulted in enthusiasm for trinitarian reflection. The project has been fraught with problems and complications from the start and has become one of the contested areas of the entire discourse. Some reject the endeavour from the outset: the trinity signifies nothing but the grammar of the salvific narrative; any probing beyond this would amount to an analogy of being. For the distracters the vast qualitative difference between God and creation should be upheld at all costs. Stock ar- 
guments have featured in the debate, for example the supposed inability of social trinitarians to establish divine unity, and the charge that terminology like person is used univocally and not analogously (cf. Gresham, 1993). Too many counter-arguments may, however, be advanced to propose this second reference to God as legitimate, albeit with qualification. For example, biblical motifs like the creation in the image of God, the imitation of God (cf. Barton, 2007; Schneider, 1989) and incorporation into the divine life through baptism render this discursive use of God possible and valid.

The approach of a number of notable and respectable contemporary scholars may be helpful for future employment of this reference to God. A theologian like Volf (1998:405) sets clear limits to the project. Ontically human beings and God are different, noetically terms like person and perichoresis could be used analogously and not univocally, and the reality of sin precludes perfect reflection. Setting limits does not imply that the possibility is ruled out, as is evident for example in Volf's own social ethic. The character of the triune God inevitably impacts on the life of those who believe and worship Him. A valid question could be raised as to whether only the quality of the action of God in the economy of salvation, but also of the being of the immanent and intradivine life should function normatively. At stake is the question of limits and boundaries, and the extent of a trinitarian ethic. Fundamental decisions and convictions may be decisive in this instance, not only about the exact relationship between economic and immanent trinity, but ultimately also about an understanding of the point of the trinitarian doctrine (cf. e.g. Haight, 1988; Jenson, 1995).

\subsection{Heuristics and Trinity}

A third potential reference to God has loomed beneath the previous ones as a motivation for theological construction. Most often this is not explicitly theorised, but a deeper scrutiny of the theological dynamics can easily disclose it. The discursive reference to God is in fact an appeal to a final horizon to solve problems. Often the understanding of God as Agent or Model is in service of a larger quest: to address theological, ecclesial, social and even ontic questions. Gunton's suggestion (1993:141-154) that the trinity generates "open transcendentals" is linked to the way in which the reference to God functions in some discourse. It may also be in line with Polkinghorne's provocative view (2004:61) that the trinity could be considered as the Theory of Everything: "a deeply intellectually satisfying candidate for the title of a true 'Theory of Everything' is in fact 
provided by Trinitarian theology". At stake in this regard is most likely an attempt to rehabilitate the practical nature of the doctrine (cf. Lacugna, 1991:1; Sigurdson, 2005:121 ff.), to assert the public relevance of faith in God (Koopman, 2007:27 ff.), and finally to address the question of truth (Marshall, 1995).

Numerous examples could illustrate the presence of this function of references to God. Only the Moltmann Festschrift addresses issues such as generosity, property (economics), interreligious dialogue, gender, and justice with reference to the trinity. For example, Coakley (2006) raises the question of grounding gender in God in order to construe it theologically from the outset. Unsatisfied with proposals about a "motherly" Father and the Spirit as "feminine" principle, she prefers to move beyond gender binaries. The trinity provides resources to destabilise basic binaries: the trinity is "an irreducible threeness that always refuses a mere mutuality of two" (Coakley, 2006:140); and the incarnation has "transgressed" the fundamental binary of divinity and humanity (Coakley, 2006:140). The trinity "ruptures" and transcends normal forms of gender understandings. Rhetorically God functions in this instance in the frame of problemsolving. The list of examples could easily be expanded. The unity/ plurality question and social relations are the most popular candidates for this treatment. My own work on trinitarian theology (cf. Venter, 2004; 2005; 2006; 2007; 2008b) has explored the implications of the trinitarian confession for mission, leadership, space and city-planning, doing theology, and interculturality.

A particular relevant application in the South African context could be mentioned, namely church unity. Since the era of Greek metaphysical speculation the problem of the one and the many has been beyond the reach of human solution. Unity and diversity do not allow for peaceful cohabitation. The implications of the trinitarian confession that God is one and differentiated, one Nature and three Persons, should be seriously considered and explored for its metaphysical, social and ecclesial promise. Perichoretic unity "solves" a major problem. In an analogous manner this could be extended to the question of unity in the church. Unity as communion of people of divergent backgrounds is possible. Identity in a trinitarian sense is maintained in an exstatic manner inasmuch that a person has an identity by virtue of gift to the other (cf. e.g. Migliore, 2003:143-147).

Solving problems with reference to the divine trinity argumentatively does obviously not imply the legitimacy or validity of the construals. Many dangers accompany these proposals. Projection, hermeneutical circularity and the God-of-the-Gap fallacy are all realities. The 
question could also be raised as to whether these attempts bear any fruit within the worshipping community that most of the time experiences faith within the parameters of the agency of God. One possible way to adjudicate the issue of validity is a closer scrutiny of biblical rhetoric itself. For example, how are references to God utilised in books like Deutero-Isaiah or Revelations. Does the particular theology of God in these materials not serve a greater social issue exile and perceived oppression? The rhetorical strategies consist of representing God in such a manner to address social exigencies.

The application of trinitarian faith to current struggles and problems should be considered one of the major advances of the so-called Trinitarian Renaissance. The debate about validity and methodology has perhaps only begun. The question as to whether God should be discursively involved could hardly be answered in the negative. The real question is rather how this dialectical movement between God and reality should proceed argumentatively. In a post-Darwinist world where naturalist reduction is a constant threat, and employing references to God heuristically is an attempt at advocating a transcendent and ultimate dimension of life that is uniquely personal.

\section{Imagination and trinitarian construction}

An awareness and recognition of these three references to God may potentially further the development of trinitarian theology as aspects of methodology crystallise. It may provide a kind of analytic grid to appreciate constructive trinitarian work, but it may also assist endeavours to inhabit expansively a trinitarian space in the world. A number of implications of the proposal could be mentioned.

- Identifying which reference functions dominantly in a discourse, or construing trinitarian proposals more deliberately along these lines is only one dimension of a sophisticated dynamics. This proposal does not pretend to exhaust the methodological question; in no way could the project of trinitarian theology be stifled with a simple straitjacket. A number of variables come into play, providing limitless possibilities. These three references could be combined in several configurations, for example, God's agency could become a model to reflect, or it could suggest an exit from a mental conundrum. The number of configurations renders trinitarian theology inherently pluralistic. 6 Most often in theological re-

6 In addition to these complex combinations, a fuller rhetoric of trinitarian assertions will attend to at least three other features, namely an operative 
flection the three references are intricately interwoven and it is not particularly easy to disentangle them. One brief example can be cited as illustration. Wolterstorff (2006) raises the intriguing question as to whether there is justice in the trinity. A tight argument boils down to a number of moves. Rendering justice implies the existence of primary justice. This, in turn, consists of treating persons with due respect for their worth (Wolterstorff, 2006:185). Then enters the trinity and love: love of attachment (delight in the other) and acknowledgement of worth go hand in hand. Justice in their relationship is connected with love for each other. "Justice in the Trinity is a constituent of love within the Trinity" (Wolterstorff, 2006:187). Analysing Wolterstorff's proposal reveals that God functions according to all three references. The aim is to find an answer to the question of justice (heuristics) and by attending to the intra-trinitarian love (agency), a solution is found and an example is set for human behaviour (modelling) "We mirror the inner life of the trinity" (Wolterstorff, 2006:187).

- Contemporary trinitarian proposals show surprising creativity and variety, and the activity could arguably be described as imaginative construction. Imagination understood in this context is expressly not illusionary, but productive of truth. See the work by Green (1989) for an excellent discussion of imagination. Imagination is the point of human-divine contact (Green, 1989:34), and that paradigmatic faculty to recognise more complex objects of cognition (Green, 1989:66). Imagination does not "image" (i.e. picture), but "imagines" (i.e. think about God analogously, what God is like) (Green, 1989:93). This is, however, more than a mere label; it conveys the nature of the task at hand. Too often the charge of speculation is directed to creative work in order to resist theological exploration. The history of the life of the triune God is a narrative of inexhaustible mystery, which grants all reflection a surplus of meaning and of recognisable grace. Trinitarian theology acquires open-ended possibilities, but simultaneously an orbit of movement or a specific grammar. A certain vocabulary which has become associated with recent discourse, for example relationality, communion, generosity, gifting, mutuality,

assumption about the basic significance of a trinitarian confession, a conviction about a trinitarian logic within traditional options, and about own interests, values and concerns. For example, an analysis of a specific constructive proposal could be read with attention to (un-)expressed views on the relationship between economic/immanent trinity, divine unity and subjectivity, and about intended ethical outcomes. 
conveys both adventure and constraints, newness and identification. A trinitarian imagination responds to the reality of this God, this economical history; it reflects this identifiable richness. The very nature of God informs the quality of the discourse. This is not theological speculation, but rather the adventure of creative obedience.

- Apart from the thematic selection, which often evidences startling surprises, for example to connect questions of gender, property or justice to God's being, the imaginative quality of recent work is introduced by an original and virtually axiomatic claim which forms the basis for further argumentation. In the case of the illustrations by Meeks, Coakley, and Wolterstorff basic understandings of property, gender and justice steer the utilisation of the three references to God. The integration of a specific theme into the mystery of the divine trinity is the crux of trinitarian rhetoric, and will determine the ultimate legitimacy of each individual project. How claims, grounds, warrants and qualifications function in the entire argumentation require further investigation. ${ }^{7}$

- These implications underline the fact that doing trinitarian theology is not a mechanical and simplistic task; it appeals to a spectrum of human capacities and responses. Each reference to God may require a unique human answer. One is tempted to refer to the cardinal virtues of faith, hope and love as corresponding reflexes. To stand before God's agency requires faith; to assert that possible solutions are offered by God's being and work is a matter of hope, and to heed God's example confronts us with the challenge of love. Doing imaginative trinitarian theology could imply this virtuous activity.

- Virtue inevitably leads to the question of ethics of methodology and discourse. Any pursuit of a rhetoric of trinitarian assertions should enquire after intended ethical effects. With theological contruals theologians perform actions with potential impacts, especially with their speaking of God (Venter, 2008a). A larger number of trinitarian proposals have been motivated by visions of alternative social ordering. By freeing trinitarian theology from the captivity of repristination, and embracing a constructivist and imaginative agenda, theologians assume responsibility for their 
intellectual work. The way in which the history of the triune God's dealing with the world is represented becomes an ethical task.

\section{Conclusion: is this reformed?}

It is unavoidable to raise the question as to whether the views proposed in this instance are aligned with a reformed logic. No theological work can claim an immunity from tradition, and I undertake my own work deliberately within a reformed framework. This article is obviously an attempt at constructive theology and not mere description, but I believe that the basic proposal that God can function in at least three legitimate ways in discourse reflects basic reformed sentiments, but also charters new ground. In a recent and excellent article Smit (2009) maps the specific reformed approach to the doctrine of the trinity. He identifies five motifs which are found in reformed theologians, namely the trinity provides the "grammar" to speak about the biblical message, it emphasises the action of the living God, it forms a "trinitarian spread" when speaking about faith, it is a pastoral message, and it has practical consequences. Smit is reticent about drawing implications for ecclesiology, ethics and anthropology from the immanent trinity (Smit, 2009:72, 75). My proposal shares the basic sentiments of Smit's discussion, except that it is open to explore extensively the implications of a triune confession. A tradition which is intentionally biblical and theocentric cannot avoid motifs like the imitatio Dei, or the consequence of faith in God for social or even metaphysical questions. The reach of the trinitarian faith is wider than mere agency, and the questions of imitation and heuristics cannot be ignored. A constructive reformed trinitarian theology should address a theological grounding of ethics, and thinking in general. The description by Smit remains trapped in matters of agency and pastoral concerns; it does not allow for a genuine imaginative development of the possibilities of the trinitarian faith. This, I believe, belongs to the heart of the reformed tradition.

The rich life of God the Father, Son and Spirit, in its fullness and mystery, and in its revelation in the economic history, expands theological discourse. Only by giving expression to the multiple ways in which this God could function in our virtuous intellectual work, do we testify to the fact that the triune God is the mystery and future of the world. 


\section{List of references}

BARTON, J. 2007. Imitation of God in the Old Testament. (In Gordon, R.P., ed. The God of Israel. Cambridge: Cambridge University Press. p. 35-46.)

COAKLEY, S. 2006. The trinity and gender reconsidered. (In Volf, M. \& Welker, M., eds. God's life in trinity. Minneapolis: Fortress. p. 133-143.)

COTTERELL, P. \& TURNER, M. 1989. Linguistics \& biblical interpretation. Downers Grove: InterVarsity.

EDWARDS, D. 1999. The God of evolution: a trinitarian theology. New York: Paulist.

FERGUSSON, D. 2006. Divine providence and action. (In Volf, M. \& Welker, M., eds. God's life in trinity. Minneapolis: Fortress. p. 153-165.)

FRETHEIM, T.E. 1997. The God who acts: an Old Testament perspective. Theology today, 54:6-18.

GREEN, G. 1989. Imagining God: theology and the religious imagination. Grand Rapids: Eerdmans.

GRENZ, S.J. 2004. Rediscovering the triune God: the trinity in contemporary theology. Minneapolis: Fortress.

GRESHAM, J.L. 1993. The social model of the trinity and its critics. Scottish journal of theology, 46:325-343.

GUNTON, C. 1993. The one, the three and the many: God, creation and the culture of modernity. Cambridge: Cambridge University Press.

GUNTON, C. 1997. The promise of trinitarian theology. 2nd ed. Edinburgh: Clark.

GUNTON, C. 2003. Father, Son \& Holy Spirit: towards a fully trinitarian theology. London: Clark.

HAIGHT, R. 1988. The point of trinitarian theology. Journal of theology, 4:191204.

HUNT, A. 2005. Trinity: nexus of the mysteries of the christian faith. Maryknoll: Orbis.

JENSON, R.W. 1995. What is the point of trinitarian theology? (In Schwöbel, C., ed. Trinitarian theology today: essays on divine being and act. Edinburgh: Clark. p. 31-43.)

KÄRKKÄINEN, V-M. 2007. The trinity: global perspectives. Louisville: Westminster John Knox.

KOOPMAN, N. 2007. Public theology in (South) Africa: a trinitarian approach. (In Symington, J., ed. South African christian handbook 2007-2008. Wellington: Tydskriftemaatskappy van die NG Kerk. p. 18-29.)

LACUGNA, C.M. 1991. God for us: the trinity and christian life. New York: Collins.

MARSHALL, B.D. 1995. "We shall bear the image of the man of heaven": theology and the concept of truth. Modern theology, 11:93-117.

MEEKS, M.D. 2006. The social trinity and property. (In Volf, M. \& Welker, M., eds. God's life in trinity. Minneapolis: Fortress. p. 13-21.)

MIGLIORE, D. 2003. The communion of the triune God: towards a trinitarian ecclesiology in reformed perspective. (In Alston, W.M. \& Welker, M., eds. Reformed theology: identity and ecumenicity. Grand Rapids: Eerdmans. p. 140-154.)

MURPHY, N.C. 1994. Reasoning and rhetoric in religion. Valley Forge: Trinity.

POLKINGHORNE, J. 2004. Science and the Trinity: the christian encounter with reality. New Haven: Yale University Press. 
SCHNEIDER, G. 1989. Imitatio Dei als Motiv der "Ethik Jesu" (In Merklein, H., Hrsg. Neues Testament und Ethik. Freiburg: Herder. S. 71-83.)

SCHWÖBEL, C. 1987. Divine agency and providence. Modern theology, 3:225244.

SCHWÖBEL, C. 1995. The Renaissance of trinitarian theology: reasons, problems and tasks. (In Schwöbel, C., ed. Trinitarian theology today: essays on divine being and act. Edinburgh: Clark. p. 1-30.)

SIGURDSON, O. 2005. Is the trinity a practical doctrine? (In Jeanrond, W.G. \& Lande, A., eds. The concept of God in global dialogue. Maryknoll: Orbis. p. 115-125.)

SMIT, D. 2009. The trinity in the reformed tradition. Journal of reformed theology, 3:57-76.

THOMPSON, T.R. 1997. Trinitarianism today: doctrinal Renaissance, ethical relevance, social redolence. Calvin theological journal, 32:9-42.

TRACY, T.F. 2003. Divine action. (In Van Huyssteen J.W.V., ed. Encyclopedia of Science and Teligion. Vol. 1. New York: MacMillan. p. 218-224.)

VAN DEN BRINK, G. 2003. De hedendaagse Renaissance van de triniteitsleer: een oriënterend overzicht. Theologia reformata, 46(3):210-240.

VENTER, R. 2004. Trinity and mission: challenges to a reformed witness in Africa today. Verbum et ecclesia, 25(2):751-768.

VENTER, R. 2005. The post-modern condition, leadership and Trinitarian echoes: 16 theses. The Reformed Ecumenical Council Agenda, The Netherlands, 2005:331-341.

VENTER, R. 2006. Space, trinity and city: an exploration. Acta theologica, 26(1):201-224.

VENTER, R. 2007. Roeping en opleiding in 'n spesifieke konteks: vyf trinitariese stellinge oor motivering en oriëntasie. Acta theologica, 27(2):205-220.

VENTER, R. 2008a. God images, ethical effects and the responsibility of systematic theology. Acta theologica, 28(2):146-164.

VENTER, R. 2008b. Onderweg na 'n teologie van interkulturaliteit: 'n trinitariese perspektief. Verbum et ecclesia, 29(2):542-561.

VOLF, M. 1998. "The trinity is our social program": the doctrine of the trinity and the shape of social engagement. Modern theology, 14:403-423.

VOLF, M. \& WELKER, M., eds. 2006. God's life in trinity. Minneapolis: Fortress.

WOLTERSTORFF, N. 2006. Is there justice in the trinity? (In Volf, M. \& Welker, M., eds. God's life in trinity. Minneapolis: Fortress. p. 177-187.)

\section{Key concepts:}

God, references to

heuristics

imagination

imitatio Dei

trinitarian theology 


\section{Kernbegrippe:}

God, verwysings na

Heuristiek

imitatio Dei

triniteitsteologie

verbeelding 
